\title{
SEJARAH PENGGUNAAN NAMA ALLAH DAN TUHAN DALAM ALKITAB
}

\author{
Oleh : Pdt. Dr. George Rumbekwan, D.Th \\ Ketua STT Erikson - Tritt Manokwari
}

\begin{abstract}
ABSTRAK
Penelitian Ini berjudul: Sejarah Singkat Bangsa Ibrani dan Bahasa Ibrani dan Perkembangannya, hingga terbentuknya Alkitab Bahasa Indonesia yang menggunakan Nama Allah dan Tuhan. Penelitian ini secara sederhana menelusuri asal-usul Israel atau bangsa Ibrani dengan bahasa Ibrani yang selanjutnya mengalami perkembangan hingga mempengaruhi terbentuk Alkitab Bahasa Indonesia. Menginat perdebatan-perdebatan yang terjadi oleh karena penggunaan namanama Allah dan Tuhan dalam Alkitab. Nama Allah dan Alkitab Bahasa Indonesia sudah digunakan 333 tahun sebelum Indonesia terbentuk sebagai suatu bangsa yang merdeka dan berdaulat.
\end{abstract}

Kata Kunci : Sejarah, Allah, Tuhan, Alkitab

\section{A. SEJARAH BANGSA IBRANI DAN BAHASA IBRANI}

Menurut Kejadian 11:1-9, "Adapun seluruh bumi, satu bahasanya dan satu logatnya. Maka berangkatlah mereka ke sebelah timur dan menjumpai tanah datar di tanah Sinear, lalu menetaplah mereka di sana. Mereka berkata seorang kepada yang lain: "Marilah kita membuat batu 
bata dan membakarnya baik-baik." Lalu bata itulah dipakai mereka sebagai batu dan tergala-gala sebagai tanah liat. Juga kata mereka: "Marilah kita dirikan bagi kita sebuah kota dengan sebuah menara yang puncaknya sampai ke langit, dan marilah kita cari nama, supaya kita jangan terserak ke seluruh bumi." Lalu turunlah TUHAN untuk melihat kota dan menara yang didirikan oleh anak-anak manusia itu, dan Ia berfirman: "Mereka ini satu bangsa dengan satu bahasa untuk semuanya. Ini barulah permulaan usaha mereka; mulai dari sekarang apapun juga yang mereka rencanakan, tidak ada yang tidak akan dapat terlaksana. Baiklah Kita turun dan mengacaubalaukan di sana bahasa mereka, sehingga mereka tidak mengerti lagi bahasa masing-masing." Demikianlah mereka diserakkan TUHAN dari situ ke seluruh bumi, dan mereka berhenti mendirikan kota itu. Itulah sebabnya sampai sekarang nama kota itu disebut Babel, karena di situlah dikacaubalaukan TUHAN bahasa seluruh bumi dan dari situlah mereka diserakkan TUHAN ke seluruh bumi."1

"Bangsa Israel berasal dari kata ivrit (Israel). Kata 'ivrith adalah istilah yang digunakan untuk menyebutkan bangsa Yahudi Oriental/Mizrahi dari Timur Tengah. Dalam sebutannya bagi orang Eropa dan Amerika adalah "ivris yaitu Yahudi Asykenazi."2 Berdasarkan fakta sejarah maupun kebenaran Alkitab bahwa Bansga Israel sebagai suatu bangsa yang suka menyeberang, yang bukan saja menyeberang laut Teberau, sungai Yordan, tetapi juga menyeberangi batas-batas wilayah bangsa-bangsa lain, menaklukkannya, dan memiliki tanah perjanjian. Itulah sebenarnya Israel disebut juga sebagai bangsa Ibrani. Kata Ibrani berasal dari akar kata: עבר ('abar "menyeberang"). Kata "abar" selanjutnya menjadi asal-usul nama Ibrani dalam Alkitab. Kata "Ibrani" sendiri berasal dari bahasa Arab, dalam bahasa Inggris disebut Hebrew. Jadi sebutan Ibrani bisa menunjukkan bahasa dan bangsa, tergantung konteks penyebutannya. Sebagai satu bangsa dijelaskan dalam (Kel.1-15), dengan tokoh Abraham (Kej. 14:13) dan Yunus (Yun. 1:9). Sebagai satu bahasa resmi, maka bahasa Ibrani adalah sebuah bahasa dalam rumpun bahasa Semit, ${ }^{3}$ sebagai berikut:

${ }^{1}$ Lembaga Alkitab Indonesia. Perjanjian Lama Ibrani-Indonesia, Diterjemahkan dari : Biblia Hebrica Stuttgartensia. (Jakarta: LAI, 1999), hlm. 15.

${ }^{2}$ Leonard C. Epafras. Diktat Ibrani Dasar (Yogyakarta: Duta Wacana, 2007), t.h. ${ }^{3}$ Ibid. 
a. Bahasa Ibrani serumpun dengan bahasa Arab, Aram (bahasa yg digunakan Yesus pada zamannya), Etiopia (Ethiopic/Coptic), Syria (Syriac).

b. Bahasa Ibrani merujuk pada bahasa yang digunakan dalam Kitab Suci Yahudi (Tanakh) atau dalam tradisi Kristen disebut Perjanjian Lama atau Perjanjian Pertama bagi kalangan Yahudi Mesianik.

c. Bahasa Ibrani merujuk berbagai bahasa kuno di tanah Palestina/Israel salah satu dialek Kanaan (Paleo-Hebrew, Archaic Hebrew), 1. Ibrani Tua/Ibrani Klasik/Ibrani Alkitab (Biblical Hebrew), 2. Ibrani Misyna (Mishnaic Hebrew) yang digunakan dalam kitab keagamaan Yahudi, Mishnah pada zaman Romawi, 3. Ibrani abad pertengahan (Medieval Hebrew) - yang digunakan dalam liturgi Yahudi abad pertengahan di Eropa dan sekitar Laut Tengah.

d. Merujuk bahasa resmi negara Israel (Ibrani Modern) Ibrani Modern adalah bahasa buatan di zaman modern, 1. Diciptakan oleh Eliezer ben Yehuda, 2. Percampuran bahasa Ibrani kuno dan abad pertengahan dengan bahasa Indo-Eropa, 3. Menggunakan sistem bahasa Indo-Eropa, sehingga tidak sepenuhnya termasuk rumpun bahasa Semit. ${ }^{4}$

Sesuai dengan kutipan ayat di atas yaitu Kejadian 11:1-9, tentang pembangunan menara babel, sangat-sangat jelas bahwa pada awalnya hanya ada satu bahasa saja. Tetapi oleh karena kesombongan manusia yang ingin menyamai Allah maka Allah Tritunggal mengacaukan bahasa manusia dan diserakkan keseluruh penjuru bumi sesuai dengan bahasa-bahasanya masing-masing. Sehingga dapat dikatakan bahwa Allah langsung menciptakan bahasa-bahasa dan memberikannya kepada setiap suku bangsa sesuai dengan rumpung keluarganya masing-masing. Hal ini terlihat jelas dari rumpung bahasa Semit melalui gambar di bahwah ini. Yang membuktikan adannya hubungan dialog antar bahasa suku bangsa yang mula-mula.

${ }^{4}$ Leonard C. Epafras. Diktat Ibrani Dasar, t.h. 


\section{Rumpun Bahasa Semit (Gambar Dimasukkan)}

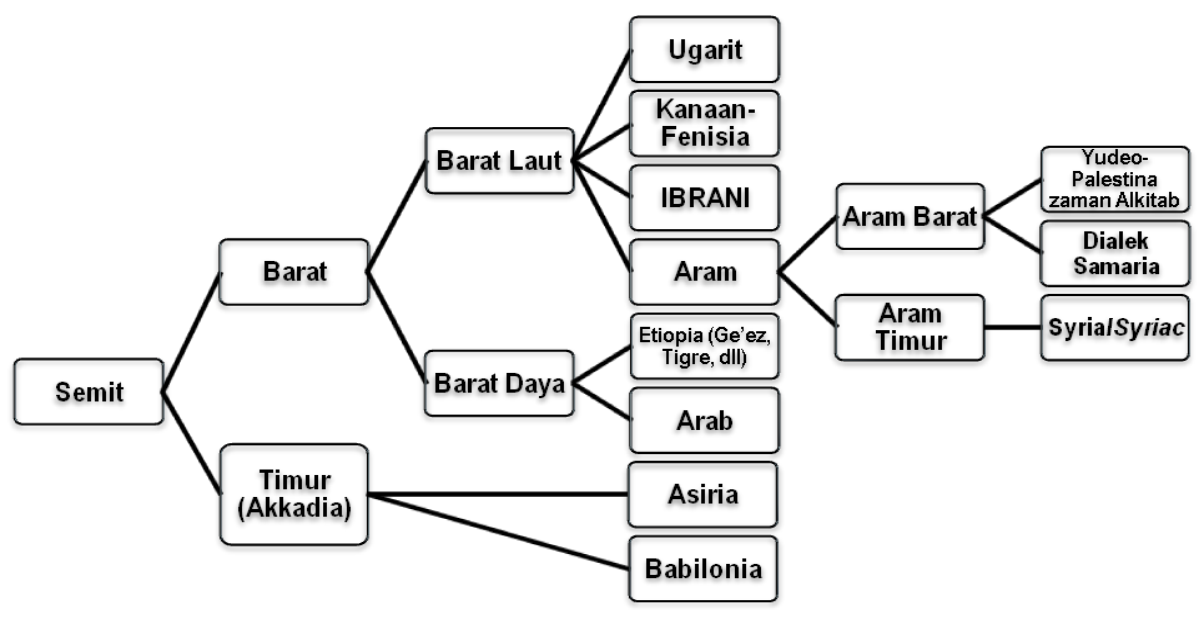

\section{Ibrani Alkitab}

Bahasa yang berkembang dan digunakan di negeri Israel/Palestina kuno pada abad 12 - 6 SM, dengan menggunakan huruf Aram!. Dalam Perjanjian Lama disebut "bahasa Kanaan" (Yes. 19:18) atau "bahasa Yehuda" (2 Raja. 18:26, 28; Yes. 36:11, 13) atau "bahasa Yahudi" (Neh. 13:24). ${ }^{5}$ Istilah Ibrani Alkitab merujuk pada:

1. Semua dialek Ibrani yang ada di Perjanjian Lama atau Tanakh. Dalam Perjanjian Lama ada berbagai dialek Ibrani, yaitu Ibrani Tua (mis. Nyanyian Debora (Hak. 2:5) dan Nyanyian Musa (Kel. 15), Muda dan Aram. Ada 268 ayat 2 yang menggunakan bahasa Aram, yaitu: Yeremia 10:11; Daniel 2:4 - 7:28; Ezra 4:8 - 6:18; 7:12 - 26. Lih. Istilah Aram dalam Perjanjian Baru, Markus 5:41; 7:34.

2. Ibrani dialek Tiberias yaitu dialek yang digunakan teks Perjanjian Lama yang paling lengkap, yaitu Kodeks Allepo dan Kodeks Leningrad.

3. Dialek Tiberias adalah dialek dari para ahli kitab dan penyalin Alkitab di daerah Galilea pada sekitar abad 7 - 10 SesM.

${ }^{5}$ Leonard C. Epafras, Diktat Ibrani Dasar, t.h. 
4. Dialek lain (> abad 1 SesM): Yaman, Asykenazi, Sefardi, Samaria, dan Naskah Laut Mati.

5. Istilah "Ibrani" sebagai rujukan bahasa, baru muncul pada abad 9 SesM oleh seorang teolog Yahudi di Babilonia (pada masa pemerintahan Islam), Saadya Gaon. "Ibrani" dipinjam dari bahasa Arab.

6. Karena merupakan bahasa kitab suci maka dalam tradisi Yudaisme disebut dengan "bahasa suci/kudus" (לשון הקודש).

7. Sesudah abad 6 SM, bahasa Ibrani sebagai bahasa sehari-hari digantikan dengan bahasa Aram yang merupakan bahasa Internasional (lingua franca) di Timur Tengah (Utara) ? Melayu (Asia Tenggara), Yunani Koine (Romawi), Arab (Timteng).

8. Bahasa Ibrani kemudian hanya menjadi bahasa keagamaan (teologi dan liturgi).

9. Bahasa Ibrani pada dasarnya tidak mempunyai huruf hidup (vokal/vowel).

10. Sesudah Bahasa Ibrani tidak lagi menjadi bahasa sehari-hari, para ahli tata bahasa Yahudi menciptakan huruf hidup untuk memastikan pembacaan yang benar. Sistem ini diciptakan antara abad 6 - 10 SesM oleh ahli bahasa yang dikenal dengan nama kelompok Masoret (Masorah). Karena teks Ibrani Alkitab dianggap suci maka huruf matinya tidak diubah dan huruf hidup diletakkan di atas, bawah dan dalam huruf mati. ${ }^{6}$

Alkitab terjemahan Ibrani standar yang sekarang digunakan adalah, "Biblica Hebraica Stuttgartensia"7 dari teks Masoret yang berdasarkan Kodeks Leningrad. Diterbitkan oleh Deutsche Bibelgesellschaft (Lembaga Alkitab Jerman) di Stuttgart, mulai tahun 1977. Dianggap teks Alkitab Ibrani yang sangat akurat bagi penelitian teks karena dilengkapi acuan antar teks (textus apparatus) yang amat lengkap. Biblia Hebraica Stuttgartensia menjadi basis bagi kebanyakan terjemahan Perjanjian Lama termasuk oleh Lembaga Alkitab Indonesia. ${ }^{8}$

${ }^{6}$ Leonard C. Epafras, Diktat Ibrani Dasar, t.h.

${ }^{7}$ Ibid.

${ }^{8}$ Ibid. 


\section{B. SEJARAH NASKAH PERJANJIAN LAMA}

Sejarah mengenai naskah Alkitab Perjanjian Lama dan kumpulan kitab-kitab di dalamnya sulit diteliti karena sebagian besar materinya sudah sangat tua. Penyelidikan ini menjadi tambah sulit karena orang Ibrani memusnahkan naskah-naskah yang lama setelah mereka selesai menyalinnya. Donald Guthrie, mengatakan bahwa:

Sebelum penemuan yang luar biasa di Qumran - yaitu ditemukannya gulungan naskah (perkamen) Laut Mati - pada tahun 1947, naskah Perjanjian Lama bahasa Ibrani yang kita miliki merupakan salinan abad ke-9 $\mathrm{M}$ dari pentateukh - lima kitab pertama dari Alkitab - dan kitab sejarah serta kitab para nabi. ${ }^{9}$ Dikatakan bahwa: Pada tahun 1947 para gembala badawi (Badui) masuk ke salah satu gua ini dan menemukan harta karung yang tak ternilai harganya. Di gua-gua ini ditemukan gulungan-gulungan Naskah Laut Mati, naskah Perjanjian Lama dan kitab-kitab lain yang berasal dari sebelum zaman Kristus. Didekatnya terdapat puin-puin Qumran, "biara" sebuah komunitas (sekelompok masyarakat kecil) yang pasti telah menyembunyikan gulungan-gulungan naskah bacaan mereka di dalam gua-gua, karena orang romawi akan segera datang menyerang. ${ }^{10}$

Paul Enns, juga mengatakan bahwa: "sebelum penemuan naskah Qumran, manuskrip yang paling tua tertanggal kira-kira 900 AD. Beberapa manuskrip dari naskah Laut Mati, termasuk di dalamnya Yesaya, Habakuk, dan yang lainnya, tertanggal jauh lebih ke belakang yaitu 125 BC. Berarti manuskrip itu seribu tatahun lebih tua dari yang semula tersedia. Konklusi utama adalah tidak adanya perbedaan yang signifikan antara gulungan Yesaya di Qumran dengan teks Ibrani Masoretik yang tertanggal sertibu tahun kemudian. Hal ini meneguhkan reliabilitas dari teks Ibrani kita yang sekaran. ${ }^{11}$

${ }^{9}$ Donald Guthrie, "Naskah dan Terjemahan," Handbook to the Bible, Pedoman Lengkap Pendalaman Alkitab (Bandung: Yayasan Kalam Hidup, 2004), hlm. 78-79.

${ }^{10}$ Guthrie, Handbook to the Bible, Pedoman Lengkap Pendalaman Alkitab, hlm. 78 .

${ }^{11}$ Paul Enns, The Moody Handbook of Theology (Malang: SAAT Literatur, 2012), hlm. 211. 
Naskah-naskah ini memuat naskah yang dikenal sebagai "Teks Masoret," yang diedit menjadi bentuk tetap kira-kira pada tahun $500 \mathrm{M}$. Semua naskah yang terdapat kemudian sama dengan naskah abad 9 M tersebut. Ini membuktikan ketelitian yang luar biasa dari para ahli kitab dalam menyalin naskah bahasa Ibrani tersebut. Dengan adanya naskah dari Qumran sebagai bukti, kita dibawa kembali lebih dari 1000 tahun ke masa silam, ke abad 1 sebelum Masehi. Hanya sedikit kutipan lengkap dari kitab-kitab Perjanjian Lama yang disimpan dengan baik. Tetapi penggalan-penggalan naskah pun sangat berharga karena membuktikan bahwa naskah-naskah itu disalin dengan sangat teliti. Penemuan-penemuan ini menambah keyakinan kita bahwa pada masamasa sebelumnya pun naskah ini disalin dengan ketelitian yang sama. Memang kita tetap ingin memperoleh bukti yang lebih tua lagi dari bagian-bagian Perjanjian Lama yang lebih kuno. Tetapi kenyataan bahwa orang Yahudi menyimpan kitab suci mereka dengan sangat akurat selama berabad-abad, sangat mendukung bahwa naskah Alkitab itu dapat dipercaya. Tentu saja hal ini bukan berarti bahwa tidak ada masalah lagi. Ada beberapa tempat yang di dalam naskah aslinya tidak jelas, sehingga editor atau penerjemah hanya berpedoman pada tempattempat yang hanya berpedoman pada tempat-tempat yang diperkirakan paling dekat kemungkinannya sebagai tempat yang dimaksud itu. ${ }^{12}$

Sekalipun demikian, dalam peristiwa-peristiwa ini terjemahannya bukan hasil perkiraan semata-mata. Kita dibantu oleh terjemahan Perjanjian Lama dalam bahasa Yunani, Septuaginta (LXX).Tentang Septuaginta, Paul Enns mengatakan bahwa:

Septuaginta adalah terjemahan bahasa Yunani dari Perjanjian Lama Ibrani untuk mengakomodasi orang-orang Yahudi yang tersebar, yang tidak lagi bisa berbahasa Ibrani. Tradisi mengatakan bahwa sekitar tujuh puluh sarjana Ibrani menterjemahkan teks Ibrani ke Yunani (nama Septuaginta berarti "tujuh puluh," jadi itu disebut LXX). ${ }^{13}$ Septuaginta adalah versi/terjemahan yang dipakai oleh orang Yahudi berbahasa Yunani pada awal era kekristenan, dan oleh orang Kristen yang mulamula. Menurut tradisi, Septuaginta berasal dari zaman Ptolemeus Filadelfus dari Mesir (285-246 sM). ${ }^{14}$ Dimana pada abad III sM,

\footnotetext{
${ }^{12}$ Guthrie, "Naskah dan Terjemahan," Handbook to the Bible, Pedoman Lengkap Pendalaman Alkitab, hlm. 78.

${ }^{13}$ Enns, The Moody Handbook of Theology, hlm. 211.

${ }^{14}$ Guthrie, "Naskah dan Terjemahan," Handbook to the Bible, Pedoman Lengkap Pendalaman Alkitab, hlm. 79.
} 
Eliezer, Iman Besar Bait Allah di Yerusalem mengutus para ahli kitab Israel ke Mesir atas undangan raja Ptolemius Philadelpus untuk menterjehmahkan Alkitab Perjanjian Lama bahasa Ibrani ke bahasa Yunani, yang disebut Septuaginta (LXX atau 70). Dalam penterjemahan tersebut istilah El/Elohim diterjemahkan menjadi Theos, dan Yahweh/Adonai menjadi Kurios (atau Kyrios). Penggantian nama dalam penterjemahan itu tidak menjadi masalah bagi orang Yahudi. ${ }^{15}$

Gulungan-gulungan Naskah yang ditemukan di daerah Laut Mati itu juga melengkapi kita dengan naskah-naskah paling kuno, yang memuat bagian-bagian Perjanjian Lama dalam bahasa Yunani. Naskah ini mempunyai banyak persamaan dengan naskah Septuaginta yang telah dikenal sebelumnya - walaupun ada beberapa variasi yang menyebabkan para pakar bertanya-tanya apakah mungkin naskahnaskah yang ditemukan di Qumran itu lebih kuno lagi. Namun, pada prinsipnya naskah dalam bahasa Ibrani lebih berbobot daripada naskah dalam bahasa Yunani, karena para editor Yunani terlalu bebas dalam menerjemahkannya. Walaupun demikian, mungkin saja di dalam naskah Alkitab bahasa Yunani ada bagian yang lebih kuno daripada naskah-naskah Ibrani yang ada. ${ }^{16}$

Selain Septuaginta, ada pula naskah lain dalam bahasa Yunani yang beredar pada awal era kekristenan. Origen dari Alexandria menyusun sebuah kitab yang dikenal dengan nama Hexapla. Di dalam kitab tersebut, ia menyejajarkan naskah Ibrani dan naskah Septuaginta dengan naskah terjemahan versi Aquila, Symmachus dan Theodotion, dan akhirnya naskah yang direvisi sendiri. Hanya dalam satu hal versiversi lain bersaing dengan Septuaginta: pada mulanya terjemahan kitab Daniel oleh Theodotion menggantikan naskah asli yang lebih buruk dalam Septuaginta. Ketika jemaat Kristen menyebar ke bagian-bagian dunia yang tidak memakai bahasa Yunani, Alkitab diterjemahkan ke dalam bahasa Latin, Aram/Siria, dan Mesir. Bersamaan dengan itu juga terjadi perkembangan dalam naskah PB sebagaimana yang dinyatakan berikut ini. ${ }^{17}$

Menetapkan sejarah tentang bagaimana tersusunnya kumpulan kitab Perjanjian Lama (kanon) yang sudah diakui itu, juga sukar karena

\footnotetext{
${ }^{15}$ Pdt. Rubin Adi Abraham, Artikel Teologi: Kontraversi Penggunaan Nama “Allah" (t.t, Agustus 2009), hlm. 2.

${ }^{16}$ Abraham, Artikel Teologi: Kontraversi Penggunaan Nama “Allah,” hlm. 79.

${ }^{17}$ Guthrie, "Naskah dan Terjemahan," Handbook to the Bible, Pedoman Lengkap Pendalaman Alkitab, hlm. 79.
} 
kurang informasi. Akan tetapi ada cukup keterangan yang menunjukkan apa saja isi Perjanjian Lama pada masa menjelang era kekristenan. Dan ini jauh sebelum tersusunnya apa yang dianggap sebagai Kitab Suci oleh Tuhan Yesus dan para rasul. Dalam tradisi Yahudi ada kepercayaan yang kuat bahwa Ezralah ahli Taurat yang menyusun kanon, walaupun kumpulan dari Pentateukh (Lima Kitab pertama dalam Alkitab) dan beberapa kitab para nabi telah ada lama sebelum zaman Ezra. ${ }^{18}$

Kitab-kitab kanon Ibrani dibagi dalam tiga kelompok - Kitab Taurat, Kitab Para Nabi, dan Tulisan Kudus (di dalamnya tercakup kumpulan Kitab Hikmat, beberapa kaiya sejarah seperti Kitab Ezra, Nehemia, dan Tawarikh, dan satu kitab nubuat, yaitu Daniel). Prolog dari kitab Apokrifa, yaitu Kitab Yesus bin Sirakh atau Ecclesiasticus (kira-kira $130 \mathrm{sM}$ ), memberikan bukti tentang pembagian menjadi tiga kelompok ini. Tetapi tidak ada petunjuk mengenai isi dari tiap bagian tersebut. Naskah-naskah yang ditemukan di perpustakaan Qumran itu mencakup semua naskah atau penggalan naskah dari seluruh kitab Perjanjian Lama kecuali kitab Ester (yang mungkin belum ditemukan). ${ }^{19}$

Yosefus, ahli sejarah abad pertama Masehi mengakui 22 kitab; Wahyu Ezra (kira-kira tahun $100 \mathrm{M}$ ) mengakui 24 kitab. Seandainya Yosefus memasukkan kitab Rut dengan kitab Haki-Hakim, maka ini akan sangat cocok. Kitab kanon bahasa Ibrani yang terdiri dari 24 buku itu setara dengan 39 buku dalam kitab kanon bahasa Yunani (karena kitab Samuel, Raja-Raja, Tawarikh, Ezra- Nehemia dan dua belas kitab para nabi kecil masing-masing hanya dihitung sebagai satu kitab dalam daftar kitab-kitab bahasa Ibrani). Sebagian besar kitab-kitab dalam Perjanjian Lama yang kita miliki dikutip dalam Perjanjian Baru. Ini menunjukkan bahwa kanon Perjanjian Lama yang digunakan Tuhan Yesus identik dengan yang biasa digunakan di antara orang Yahudi dan dikenal Yosefus. Kitab-kitab yang dikenal sebagai Apokrifa (Deuterokanonika) - yang dimasukkan dalam kanon Yunani tetapi dikeluarkan dari kanon Ibrani - jelas tidak dianggap mempunyai kedudukan yang sama dengan Kitab Suci pada zaman para rasul. Ayatayat dari Deuterokanonika tidak pernah dikutip di dalam Perjanjian

\footnotetext{
${ }^{18}$ Guthrie, "Naskah dan Terjemahan," Handbook to the Bible, Pedoman Lengkap Pendalaman Alkitab, hlm. 79.

${ }^{19}$ Ibid.
} 
Baru sebagai ayat yang berotoritas. Dikemudian hari kalangan tertentu menghargai kitab-kitab Apokrifa ini. Tetapi di kalangan orang-orang yang lebih menghormati naskah Ibrani, kitab Apokrifa tidak dianggap sebagai kanon Kitab Suci.

Selain Septuaginta dan Naskah laut mati (Qumran), ada juga Pentateukh Orang Samari dan Targum Aramaik. Pentateukh Orang Samaria adalah terjemahan dari kitab-kitab Musa dibuat memfasilitasi ibadah di Samaria di Gunung Gerizim (sebagai saingan Yerusalem). Terjemahan itu berdiri sendiri dari teks Masoretik dan karena itu tertelusur jauh ke belakang, yaitu abad ke kempat BC, maka terjemahan itu merupakan saksi yang bernilai untuk teks Perjanjian Lama. Meskipun ada sekitar enam ribu perbedaan dengan teks Masoretik, kebanyakan dari perbedaan itu adalah yang tidak berarti, yaitu yang berhubungan dengan tata bahasa dan pelafalan. ${ }^{20}$

Targum Aramaik, sangat dibutuhkan karena setelah membuangan dari Babel, orang Yahudi pada umumnya telah meninggalkan Ibrani dan memakai Aramaik. Hal itu menjadi suatu kebutuhan untuk menyediakan Kitab Suci bagi orang Yahudi dalam bahasa sehari-hari mereka. Hasilnya adalah Targum, targum artinya "terjemahan" atau "parafrasa (menulis dengan kata-kata sendiri)," dan mereka cukup bebas dalam menceritakan kembali catatan Alkitab; namun demikian, mereka "memberikan latar belakang yang bernilai untuk studi Perjanjian Baru selain memberikan kesaksian untuk teks Perjanjian Lama." 21

\section{TERSUSUNNYA NASKAH PERJANJIAN BARU}

Meskipun kita tidak memiliki autograf dari Perjanjian Baru, namun demikian, kesaksian untuk kitab-kitab Perjanjian Baru dapat kita temui. Manuskrip Papirus. Manuskrip-manuskrip ini tua dan merupakan kesaksian yang penting. Misalnya, Papirus Chester Beatty tertanggal abad ketiga. ${ }^{22}$ Manuskrip Unicial. Kira-kira dua ratus empat puluh manuskrip disebut manuskrip uncial dan dapat dikenali dengan hurufhuruf besar. Codex (artinya "kitab") Sinaiticus berisi semua Perjanjian

\footnotetext{
${ }^{20}$ Enns, The Moody Handbook of Theology, hlm. 211.

${ }^{21}$ Ibid.

${ }^{22}$ Ibid.
} 
Baru tertanggal 331 AD. Codeks Vaticanus berisi hampir keseluruhan Perjanjian Baru, tertanggal dari abad ke empat, dan diperhitungkan sebagai salah satu manuskrip yang paling penting. Alexandrinus, tertanggal abad kelima, berisi semua Perjanjian Baru kecuali bagian dari Matius dan adalah menolong untuk menentukan teks Wahyu. Yang lain termasuk Codeks Ephraemi (abad kelima), Codeks Bazae (abad ke5 dan 6), dan Codeks Washington (abad ke-4 dan 5). ${ }^{23}$

Manuskrip miniscule. Ada sekitar dua ribu delapan ratus manuskrip dalam huruf kecil biasanya dalam tulisan tangan. Mereka secara umumnya tidak setua dari manuskrip unicial. Sebagian dari miniscule menyatakan tipe teks yang sama dan menunjukkan memiliki suatu hunungan "keluarga." Demikian manuskrip itu dikategorikan. ${ }^{24}$

Versi-versi. Sejumlah versi-versi yang terdahulu dari Perjanjian Baru juga menolong dalam mengerti teks yang benar. Beberapa versi Syriac yang ada, di antaranya Diatessaron Tatian (170 AD), Old Syriac (200 AD), Peshitta (abad Kelima), dan Syriac Palestina (Abad kelima). Latin Vulgata, diterjemahkan oleh Yerome (400 AD), mempengaruhi gereja barat. Terjemahan Coptik (diterjemahkan dalam abad ketiga), termasuk Versi Sahidic dan Versi Bohairic, mempengaruhi Mesir. ${ }^{25}$

Melalui studi manuskrip Yunani dan versi-versi yang mula-mula, kritik teks telah mampu menentukan teks yang dengan substansial dari tulisan-tulisan asli. Adalah nyata bahwa tangan Allah telah memelihara macam-macam teks sepanang abad untuk memampukan para ahli untuk menyusungnya dan merekonstruksi teks itu sedekat mungkin pada tulisan aslinya. ${ }^{26}$

\section{TERJEMAHANN-TERJEMAHAN ALKITAB}

Kebanyakan orang di dunia membaca Alkitab bukan dalam bahasa aslinya, tapi dari kaiya terjemahan. Sejarah pe-nerjemahan Alkitab dimulai pada abad ke-3 SM dan terus berlangsung sampai kini, sementara para pakar dan ahli bahasa diseluruh dunia bekerja keras untuk membuat firman Allah dimengerti oleh orang-orang di mana pun.

\footnotetext{
${ }^{23}$ Enns, The Moody Handbook of Theology, hlm. 211.

${ }^{24}$ Ibid.

${ }^{25}$ Ibid.

${ }^{26}$ Ibid.
} 


\section{Bahasa-bahasa Alkitab}

Alkitab pada mulanya ditulis dalam tiga bahasa: Ibrani, Aram, dan Yunani. Kebanyakan Alkitab PL ditulis dalam bahasa Ibrani, Aram, dan Yunani. Kebanyakan Alkitab Perjanjian Lama ditulis dalam bahasa Ibrani, bahasa kuno yang digunakan orang Yahudi. Beberapa bagian ditulis dalam bahasa Aram, suatu bahasa Semit yang serumpun, yang digunakan sebagai bahasa perdagangan di Timur Dekat zaman dahulu. Sejak abad ke-1, kebanyakan orang Yahudi di Israel menggunakan bahasa Aram sebagai bahasa ibu. Bahasa Ibrani digunakan terbatas hanya dalam konteks keaga-maan (mirip bahasa Latin pada Abad Pertengahan). Sejak pe-naklukan oleh Aleksander Agung pada abad ke3 SM, bahasa Yunani menggantikan bahasa Aram -sebagai bahasa daeans di Mediterania timur. Orang-orang Yahudi yang terlibat dalam per-dagangan dan urusan resmi dengan orang bukan-Yahudi harus berbahasa Yunani. Yesus mungkin menggunakan tiga bahasa, berbicara dan mengajar terutama dalam bahasa Aram, mem-baca Kitab Suci dalam bahasa Ibrani di sinagoge, dan ber-komunikasi dengan orangorang bukan-Yahudi dalam bahasa Yunani. Ketika orang-orang Kristen membawa berita Injil ke luar Palestina, mereka berbicara dan menulis terutama dalam bahasa Yunani. Seluruh Alkitab PB ditulis dalam bahasa Yunani, kecuali beberapa kata Tuhan Yesus yang ditulis dalam bahasa Aram (mis. Mrk. 5:41; 7:34; 14:36). ${ }^{27}$

\section{Sejarah Penerjemahan Alkitab}

Versi-versi kuno. Menjelang abad ke-3 SM, orang-orang Yahudi di Mesir berbicara dalam bahasa Yunani dan bukan bahasa Ibrani sehingga muncul kebutuhan akan versi bahasa Yunani dari Kitab Suci bahasa Ibrani. Hasilnya adalah Septua- ginta (LXX, sebagaimana yang sudah dibahas sebelumnya). Sejak abad ke-I, Septuaginta adalah Alkitab utama bagi orang Yahudi diaspora (yang tersebar, terceraiberai), yaitu mereka yang tinggal di luar Israel. Kebutuhan serupa muncul di Israel karena kebanyakan orang Yahudi sekarang berbahasa Aram dan bukan Ibrani lagi. Setelah teks Ibrani dibaca dalam ibadah di

${ }^{27}$ Philip Johnston, IVP Introduction to the Bible. Pengantar Untuk Mengenal Alkitab (Bandung: Yayasan Kalam Hidup, 2011), hlm. 34. 
sinagoge, ada parafrase atau penjelasan dalam bahasa Aram yang disebut Targum, agar umat dapat mengerti. Targum-tar- gum ini lamakelamaan disediakan dalam bentuk tulisan. ${ }^{28}$

Kebutuhan akan terjemahan juga muncul dalam jemaat mula-mula, yakni ketika para misionaris Kristen mulai mewartakan Injil sampai keluar dari wilayah yang berbahasa Yunani. Versi-versi dalam bahasa Latin dan Siria diterbitkan pada abad ke-2, dan banyak lagi yang menyusul: Koptik (bahasa Mesir), Armenia, Georgia, Slavia, Etiopia, dan lain-lainnya. Versi kuno yang paling bertahan ialah Vulgata dalam bahasa Latin, diter-bitkan oleh Jerome, bapa gereja mula-mula, pada akhir abad ke-4. Menurut amanat Paus Damasus I, Vulgata dimaksudkan untuk menggantikan versi bahasa Latin yang kuno. Terjemahan Jerome yang sangat baik itu menjadi Alkitab standar bagi gereja Katolik selama lebih dari 1.000 tahun. "Vulgata" berasal dari kata Latin yang artinya "umum" dan merujuk pada bahasa daerah, bahasa sehari-hari umat.

Berbagai versi mula-mula dalam bahasa Inggris. Walaupun Vulgata dimaksudkan sebagai terjemahan dalam bahasa umum, menjelang abad pertengahan bahasa Latin hanya dimengerti oleh masyarakat elit. Karena khawatir dapat menimbulkan kesesatan jika tiap orang menafsirkan Alkitab sendiri, gereja menetapkan batasan-batasan ketat bagi penerbitan versi-versi bahasa daerah. Namun, orang-orang seperti John Wycliff, seorang teolog dari Oxford, percaya bahwa firman Allah adalah untuk semua orang. Pada tahun 1382, Wycliff dan rekanrekannya menerbitkan untuk pertama kalinya terjemahan seluruh Alkitab dalam bahasa Inggris. ${ }^{29}$

Dengan ditemukannya mesin cetak oleh Johannes Gutenberg pada tahun 1450 dan terjadinya Reformasi Protestan pada awal abad ke-16, penerbitan Alkitab pun berkembang. Pada tahun 1526, William Tyndale menerbitkan cetakan pertama Alkitab PB dalam bahasa Inggris. Terjemahan Tyndale yang sangat baik itu, yang diterjemahkan langsung dari bahasa Yunaninya, menjadi standar bagi akurasi dan gaya sehingga menjadi model dari se-mua versi bahasa Inggris selanjutnya. Namun, terjemahan-terjemahan dalam bahasa daerah atau bahasa sehari-hari di Inggris masih tetap dianggap melanggar hukum sehingga Tyndale terpaksa mengungsi ke daratan Eropa untuk menyelesaikan karyanya.

\footnotetext{
${ }^{28}$ Johnstop, IVP Introdution to the Bible, hlm. 34.

${ }^{29}$ Ibid.
} 
Akhirnya, ia diculik, dipenjarakan, dan dihukum mati. Warisan Tyndale ada sampai sekarang, di mana penerjemah-penerjemah Alkitab internasional mengalami kekerasan dan bahkan mati syahid demi membawa nama ke tempat-tempat paling terpencil di dunia. ${ }^{30}$

Versi yang sudah diakui secara resmi atau versi King James. Perubahan iklim politik di Inggris serta popularitas kaiya Tyndale mengakibatkan larangan-larangan melunak dan versi bahasa Inggris berkembang pesat. Authorized Version (versi yang diakui resmi), yang di Amerika Utara dikenal sebagai King James Version, dimaklumkan oleh Raja James I dari Inggris pada tahun 1604 sebagai kompromi antara dua versi Inggris yang bersaing, Bishop's Bible (1568), yaitu Alkitab resmi gereja Inggris, dan Geneva Bible (1560) yang disukai kaum Puritan. Penerjemahannya diselesaikan dalam waktu tujuh tahun oleh 47 pakar Alkitab terkemuka di Inggris dan diterbitkan pada tahun 1611. Walaupun seperti semua versi yang baru Authorized Version (AV) pada mulanya ditolak oleh sebagian orang, terjemahan tersebut segera menjadi versi bahasa Inggris yang paling luas dipakai pada zamannya dan akhirnya menjadi Alkitab bahasa Inggris yang paling populer sepanjang masa. ${ }^{31}$

Revisi dari Authorized Version. Meskipun AV tetap merupa-kan Alkitab bahasa Inggris yang paling utama selama 300 tahun, perubahan-perubahan dalam bahasa Inggris, kemajuan dalam pengetahuan Alkitab, serta penemuan naskah-naskah yang le-bih tua dan lebih dapat diandalkan mengakibatkan perlunya revisi. Pada tahun 1870, gereja Inggris menetapkan Revised Version (RV, 1881-1885, versi yang direvisi). Sebuah revisi ter-pisah, American Standard Version (ASV), diterbitkan pada tahun 1901 untuk mencerminkan selera para pakar Amerika. Meski-pun versi-versi tersebut tidak dapat mengalahkan kepopuleran AV, mereka memulai suatu era peneijemahan dan revisi yang terus berlangsung sepanjang abad ke-20 sampai memasuki abad ke-21. ${ }^{32}$

${ }^{30}$ Johnston, IVP Introduction to the Bible. Pengantar Untuk Mengenal Alkitab, hlm. 36.

${ }^{31}$ Ibid.

${ }^{32}$ Johnston, IVP Introduction to the Bible. Pengantar Untuk Mengenal Alkitab, hlm. 36. 


\section{Versi-versi Kontemporer Dan Prinsip-prinsip Penerjemahan Modern}

Versi-versi bahasa Inggris masa kini dapat dikategorikan dalam berbagai cara. Ciri pertama adalah antara versi-versi yang terdapat dalam jalur revisi langsung dari AV dan pendahulu-nya, serta versiversi "baru" yang diteijemahkan langsung dari bahasa Ibrani dan bahasa Yunani. Beberapa yang terdapat da-lam tradisi AV adalah Revised Standard Version (RSV, 1952), New American Standard Bible (NASB, 1971), Revised Authorized Version (RAV, 1982), New Revised Standard Version (NRSV, 1990), serta English Standard Version (ESV, 2001). Versi-versi baru yang tidak berkaitan langsung dengan AV termasuk New English Bible (NEB, 1970), Good News Bible (GNB, 1976), New International Version (NTV, 1978; New Century Version (NCV, 1986), Revised English Bible (REB, 1989), Contemporary English Version (CEV, 1995), New Living Translation (NLT, 1996), serta Today's New International Version (TNIV, 2005). Kebanyakan ver-si tersebut dapat dikategorikan sebagai versi-versi "Protestan" karena tim-tim penerjemahnya sebagian besar adalah orang-orang Protestan. Versi-versi Katolik Roma yang terbaru terutama adalah Jerusalem Bible (JB, 1966), New American Bible (NAB, 1970), dan New Jerusalem Bible (NJB, 1985). Pada tahun 1985, Masyarakat Penerbit Yahudi menerbitkan Tanakh, sebuah terje-mahan terbaru Kitab Suci bahasa Ibrani orang Yahudi. ${ }^{33}$ Satu lagi perbedaan penting di antara versi-versi Alkitab mo-dern adalah filsafat penerjemahannya. Versi terjemahan harfiah formal equivalent) atau "kata demi kata" berusaha untuk sedekat mungkin mengikuti tata bahasa dam kosa kata bahasa Ibrani atau bahasa Yunani yang aslinya.

Versi-versi terjemahan dina-mis (functional equivalent) atau versi idiom berusaha memprio-ritaskan penerjemahan menurut makna dari teksnya, apa pun bentuknya. Misalnya, RSV menerjemahkan Kisah Para Rasul 1:22 sangat harfiah: "Kabar tentang hal ini sampai ke telinga jemaat di Yerusalem . . . Menyadari bahwa "telinga jemaat" adalah kiasan dalam bahasa Yunani dan bukan bahasa Inggris menerjemahkannya: "Kabar tentang hal ini sampai kepada jemaat di Yerusalem." RSV menerjemahkannya lebih dekat ke bentuk Yunani,

${ }^{33}$ Johnston, IVP Introduction to the Bible. Pengantar Untuk Mengenal Alkitab, hlm. 37. 
sedangkan GNB menangkap makna idiomatiknya dalam bahasa Inggris yang wajar.

Tidak ada versi yang murni dalam kedua filsafat terjemahan. Karena tidak ada bahasa yang sama, semua versi harus sering mengartikan makna kiasan agar dapat dimengerti. Perbedaannya adalah seberapa jatah kebebasan para penerjemah untuk mengubah bentuk agar menghasilkan bunyi bahasa Inggris yang wajar. Semua versi Alkitab berada dalam suatu spektrum antara bentuk dan makna. Beberapa versi baru yang umumnya menekankan kesamaan bentuk, meliputi RSV, NASB, RAV, NRSV, dan ESV. Versi yang menekankan kesamaan isi, meliputi GNB, CEV, NCV, dan NLT. Versi-versi yang ada di antara keduanya adalah NIV, REB, NAB, NJB, dan TNIV. Banyak orang Kristen memakai salah satu di antaranya sebagai Alkitab 'serba guna'. (Kebanyakan kutipan dalam Pengantar untuk Mengenal Alkitab ini dalam teks Inggrisnya diambil dari TNIV). ${ }^{34}$

Ada kekuatan dan kelemahan dalam terjemahan harfiah dan dinamis, dan para pelajar firman harus dianjurkan untuk memakai versi yang bervariasi diantara spektrum terjemahan itu. Kedua jenis penerjemahan memunyai tempat yang penting dalam pemahaman Alkitab. Versi terjemahan harfiah menolong karena mencermati struktur bentuk dari bahasa aslinya, mengidentifikasi idiom Ibrani dan Yunani, menunjukkan apa yang berbeda dalam teks, dan menelusuri bentuk kiasan- kiasan verbal serta kata-kata yang sering muncul. Versiversi terjemahan dinamis lebih berguna untuk mengomunikasikan secara tepat makna dari teks tersebut, dan untuk memberikan kejelasan, keterbacaan, dan bunyi bahasa yang wajar. ${ }^{35}$

Penerjemahan Alkitab tetap menjadi perhatian penting bagi gereja. Firman Allah dimaksudkan untuk semua orang di segala tempat, tetapi masih ada kelompok etnis di dunia ini yang belum memiliki Alkitab dalam bahasanya sendiri. Selain itu, ada kebutuhan untuk menyesuaikan versi yang ada dengan perubahan atau perkembangan bahasa. Bahasa selalu berubah, menuntut revisi berkala untuk mengikuti idiom masa kini dan menghindari kekolotan bahasa (mis. Dalam AV terdapat pemakaian kata kuno 'menyedihkan' untuk menyatakan 'penuh belas kasihan' dalam Yak. 5:11). Kemajuan-

\footnotetext{
${ }^{34}$ Johnston, IVP Introduction to the Bible. Pengantar Untuk Mengenal Alkitab, hlm. 37.

${ }^{35}$ Ibid., hlm. 38.
} 
kemajuan pengetahuan Alkitab dan penemuan-penemuan arkeologi juga memunculkan kebutuhan untuk senantiasa menilai ulang dan meningkatkan versi-versi yang ada. Meskipun tidak ada versi Alkitab yang sempurna, ada tujuan yang mantap untuk mengkomunikasikan maksud teks yang kudus dengan ketepatan serta kejelasan. ${ }^{36}$

\section{E. FAKTA SEJARAH}

Kata "Allah" adalah kata untuk menyebut Tuhan dalam bahasa Arab dan nama ini sudah dipakai jauh sebelum agama Islam hadir di abad ke 7 SM. Agama semitik (Yahudi, Kristen, Islam) berasal dari rumpun Sem. Arphaksad adalah putra Sem yang menurungkan bangsa Ibrani (Yahudi) dan Aram (Juga putra Sem), yang menurungkan bangsa Aram dan Arab (Kej.10:21 dst).

Abraham berasal dari Mesopotamia dan berbahasa Aram, setelah hijrah ke Palestina, Ishak anaknya pengawini Ribka anak Laban yang tingga di Mesopotamia. Alkitab mencatat Laban adalah orang Aram dan berbahasa Aram (Kej. 31:20). Yakub, Pura Ribka mengawini Lea dan Rahel (anak-anak Laban). Jadi orang Israel keturunan yakub mengikuti bahasa Aram.

Menurut Bambang Noorsena (seorang yang fasih berbahasa Arab dan pernah belajar di Kairo) dalam bukunya, 'The History of Allah,' menjelasakan bahwa istilah El, Elohim, Eloah (bhs Ibrani), Elah, Elaha (bhs Aram) dan Ilah, Allah (bhs Arab) berasal dari akar kata Semitik yang sama.

Perlu ditambahkan bahwa "Allah" sudah dikenal sebelum Alquran diwahyukan. Umat Kristen yang berbahasa Arab dari gereja-gereja timur tengah menggunakan nama "Allah" untuk memanggil Tuhan. Penegasan Prof. Dr. Nurcholish Madjid (sendekiawan Muslim) yang dikutip oleh Bambang Nurseno, mengatakan bahwa: sesuai dengan ayat-ayat alquran. Nama 'Allah' disembah juga oleh orang-orang Yahudi dan Kristen. Dengan kata lain bertentangan dengan fakta sejarah bahwa sebelum dan sesudah Islam, kata 'Allah' digunakan bersama-sama oleh pengikut Musa (Yahudi), pengikut Yesus (Kristen) dan umat Muhammad (Islam).

${ }^{36}$ Johnston, IVP Introduction to the Bible. Pengantar Untuk Mengenal Alkitab, hlm. 39. 
Sehingga Prof. Dr. Olaf Schumann seorang teolog Kristen ahli Islam, pernah belajar 3 tahun di Universitas Al Azhar, Kairo. Menyebut mereka yang menyangkal fakta sejarah ini sebagai "bid'ah baru."

Dari fakta di atas dapat dikatakan bahwa Nama 'Allah' adalah nama Arab untuk menyebut Tuhan Abraham (Bapa leluhur dari tiga agama besar: Yahudi, Kristen, Islam) yang berbahasa Arab semuanya menggunakan nama 'Allah' tanpa masalah. Bahkan menurut sebuah artikel, ada 29 juta orang berbahasa Arab yang beragama Kristen dan semuanya menyebut nama "Allah, dan dikalangan ini beredar empat versi Alkitab berbahasa Arab yang menggunakan kata 'Allah.'

\section{F. TERSUSUNNYA ALKITAB BAHASA INDONESIA}

Agama Kristen masuk ke Indonesia melalui orang-orang Eropa Barat, yaitu orang Portugis, Spanyol dan Belanda, pada abad ke 16 dan 17. Memang seorang Missionaris Barat pada abad 14 yang dua kali singgah di Sumatera, tetapi tidak meninggalkan bekas. Orang Portugis dan Spanyol membawa agama Katolik, yang sifatnya hirarkis. Jemaat tunduk pada kekuasaan gereja. Waktu itu menjadi orang Kristen berarti menerima kebudayaan Barat. Bahasa Ibadah pun diseragamkan di seluruh dunia, yaitu bahasa latin, demikian pula kitab suci (Alkitab) dalam ibadah itu. Seabad setelah orang Portugis, datanglah orang Belanda ke Indonesia. Mereka penganut Reformasi, khususnya reformasi Calvin. Hirarki tidak ada lagi di dalam gereja. Ibadah tidak usah seragam. Alkitab harus disebarkan seluas mungkin dalam bahasa yang dimengerti orang. Gereja-gereja mulai didirikan di Indonesia. Jemaat-jemaatnya harus menerima tata ibadah serta pengakuan iman yang berlaku di negeri Belanda. Mereka dipimpin dan diurus oleh tenaga yang didatangkan dari Negeri Belanda atau yang telah didik di situ. Semuanya diatur supaya tidak mengganggu monopoli perdagangan VOC di Indonesia. ${ }^{37}$

Meski penyebaran agama Kristen Katolik maupun protestan (Reformasi) tersendat-sendat dan menghadapi ancaman kandas, ada juga tokoh yang berhasil menanamkan kekristenan yang memberi kesan baik, misalnya: Fransiskus Xaverius di Maluku (1546 - 47)

${ }^{37}$ Dra. Ny. Yap Wei Fong, dkk, Handbook to the Bible. Pedoman Lengkap Pendalaman Alkitab (Bandung: Yayasan Kalam Hidup, 2004), hlm. 91-92. 
dengan misi gaya barunya. Dalam perkembangan agama Kristen selanjutnya baik oleh pihak Katolik maupun Protestan didirikan sekolah-sekolah. Kemudian pendeta-pendeta Belanda dan pihak Protestan berpendapat bahwa Alkitab harus disediakan dalam bahasa setempat. Maka dimulailah usaha menterjemahkan Alkitab ke dalam bahasa Indonesia. ${ }^{38}$

Penggunaan Nama Allah dan TUHAN di dalam Alkitab (LAI), telah digunakan tahun 1612, tatkala Albert Cornelius Ruyl menerjemahkan Alkitab ke dalam bahasa Melayu (Injil Markus) yang diterbitkan tahun 1929 oleh Jan Jacobiz Palestein. Terjemahan kitab Kejadian tahun 1662 dan Perjanjian Baru tahun 1668 oleh Daniel Browerios dalam bahasa Melayu. Dan terjemahan Alkitab lengkap oleh Mechior Leideker dilakukan pada 1691-1701 dan diteruskan oleh Francois Valentyn, disempurnakan oleh Pieter can der Vorm, George Henric Wernly, Engelbertus Cornelius Ninabers, dan Arnoldus Brants, dimana telah dibandingkan dengan bahasa Asli Alkitab, bahasa Arab, Aram, Latin, Inggris, Jerman, Perancis serta Spanyol kemudian dicetak tahun 1733 (huruf latin) dan 1758 (edisi huruf Arab). ${ }^{39}$ Dengan demikian penggunaan Nama ALLAH dan Tuhan sudah digunakan dalam Alkitab bahasa Indonesia selama 333 tahun sebelum Indonesia terbentuk sebagai satu negara yang merdeka dan berdaulat.

\section{G. KESIMPULAN}

Penulisan ini adalah merupakan penelitian singkat tentang sejarah singkat bangsa Ibrani dan Bahasa Ibrani dan perkembangannya hingga terbentuknya Alkitab Bahasa Indonesia yang menggunakan nama ALLAH dan TUHAN. Pertanyaan paling penting dalam kesimpulan ini adalah: Pertama; Sebutan atau Nama ALLAH dan TUHAN berasal dari mana? Kedua: Siapakah yang paling berhak menggunakan nama TUHAN dan ALLAH? Ketiga: Apakah salah menggunakan nama TUHAN atau ALLAH dalam sebutan lain sesuai bahasa setiap suku bangsa?

\footnotetext{
${ }^{38}$ Fong, dkk, Handbook to the Bible. Pedoman Lengkap Pendalaman Alkitab, hlm. 91-92.

${ }^{39}$ Yakob Tomatala, Colloquium Biblicum, Bidang Ilmu Biblika, Teologi Alkitab (Jakarta: STT Jaffray, 2013), hlm. 37.
} 
Jawabannya adalah pertama: ALLAH telah mencipatakan langit bumi dan seluruh isinya dan menempatkan manusia sesuai dengan kehendak-Nya. Sebut saja bangsa Ibrani. Apakah bangsa ini adalah bangsa yang baik sehingga dipilih Allah? tentu saja tidak, justru sebaliknya bangsa Ibrani atau Israel adalah yang paling jahat dihadapan-Nya, sehingga dipilih sebagai sarana berkat Allah. Jadi tentang Asal-usul nama TUHAN atau ALLAH perlu diingat bahwa tidak ada nama yang turung dari Sorga, apapun Nama-Nya itulah bahasa manusia. Seandainya Tuhan berkehendak supaya hanya ada satu bahasa saja maka peristiwa Menara Babel tidak akan terjadi, dan ataupun terjadi, tetapi bahasa manusia tetap satu saja walaupun diserakkan keseluruh dunia.

Nama ALLAH telah digunakan oleh umat Kristen Arab, sebelum Islam mulai berkembang pada abad ke-7 di tanah Arab. Walaupun demikian tidak dapat diklaim oleh umat Kristen sebagai pengguna nama Nama ALLAH yang pertama, karena nama ALLAH dapat digunakan oleh semua agama Simitik. Hanya ketika digunakan ditujukan kepada Maksud, tujuan atau pribadi yang berbeda. Jadi ketika umat umat Kristen menggunakan nama ALLAH menunjukkan kepada ALLAH Abraham, Ishak dan Yakub, yaitu ALLAH Tritunggal Yang Esa.

Dengan demikian secara khusus penggunaan Nama ALLAH dan TUHAN sudah digunakan dalam Alkitab bahasa Indonesia selama 333 tahun sebelum Indonesia terbentuk sebagai satu negara yang merdeka dan berdaulat.

\section{DAFTAR PUSTAKA}

Abraham, Pdt. Rubin Adi. Artikel Teologi: Kontraversi Penggunaan Nama “Allah.” t.t, Agustus 2009.

Enns, Paul. The Moody Handbook of Theology. Malang: SAAT Literatur, 2012.

Epafras, Leonard C. Diktat Ibrani Dasar. Yogyakarta: Duta Wacana, 2007. 
Fong, Dra. Ny. Yap Wei dkk. Handbook to the Bible. Pedoman Lengkap Pendalaman Alkitab. Bandung: Yayasan Kalam Hidup, 2004.

Guthrie, Donald. "Naskah dan Terjemahan." Handbook to the Bible, Pedoman Lengkap Pendalaman Alkitab. Bandung: Yayasan Kalam Hidup, 2004.

Johnston, Philip. IVP Introduction to the Bible. Pengantar Untuk Mengenal Alkitab. Bandung: Yayasan Kalam Hidup, 2011.

Lembaga Alkitab Indonesia. Perjanjian Lama Ibrani-Indonesia, Diterjemahkan dari : Biblia Hebrica Stuttgartensia. Jakarta: LAI, 1999.

Munthe, Eben. "Implikasi Penggunaan 'El' Dan 'YHWH' Dalam Kekristenan Masa Kini." KURIOS (Jurnal Teologi dan Pendidikan Agama Kristen) 5, no. 1 (2019): 54-73.

Siahaya, Karel Martinus. "Dampak Sosial Politik Terhadap Perkembangan Ekonomi Umat Allah Zaman Perjanjian Lama." Jurnal Teruna Bhakti 2, no. 1 (2019): 12-26.

Tomatala, Yakob. Colloquium Biblicum, Bidang Ilmu Biblika, Teologi Alkitab. Jakarta: STT Jaffray, 2013. 